\title{
BLENDED LEARNING AS A METHOD FOR IMPROVING STUDENTS' ACHIEVEMENT IN DERMATOTHERAPY: A PRELIMINARY STUDY
}

\author{
Sri Linuwih Menaldi ${ }^{1 *}$, Hanny Nilasari ${ }^{1}$, Githa Rahmayunita ${ }^{1}$, Siti Farida ${ }^{2}$, Nanda L. Prasetya ${ }^{3}$ \\ ${ }_{1}^{1}$ Department of Dermatology and Venereology, Faculty of Medicine, Universitas Indonesia/dr. Cipto Mangunkusumo Hospital, \\ Jakarta - INDONESIA \\ ${ }^{2}$ Department of Medical Pharmacy, Faculty of Medicine, Universitas Indonesia, Jakarta - INDONESIA \\ ${ }^{3}$ Master of Medical Sciences Program in Medical Education, Harvard Medical School, Boston - USA
}

Submitted: 17 April 2020; Final Revision from Author: 02 October 2020; Accepted: 07 October 2020

\begin{abstract}
Background: Dermatotherapy is an important topic in Dermatology and Venereology module. The time allocated for dermatotherapy topic is limited, so that the development of learning method is needed to achieve the learning objectives. Blended learning is a combination of e-learning and face to face lecture session. This method is often used when there is less time available for lecturing and limited number of teachers. This learning method is expected to be more effective and efficient for the students and also the teachers. This study was conducted to examine the effectiveness of blended learning method used in dermatotherapy topic, and to identify the obstacle of using this method.
\end{abstract}

Methods: This study is a cross sectional study, using quantitative and qualitative approach, involving 22 fifth-year medical students of Faculty of Medicine Universitas Indonesia who enrolled in dermatology and venereology module. We collected data from questionnaire, pre and post-test, and feedback from the students. Comparison of pre-test and posttest results were analysed using paired T test, and followed by bivariate test of students' characteristic, gadget usage and e-learning activities associated with the increased post-test score.

Results: An increased in post-test score was found to be statistically significant (p<0.05). Approximately 95,4\% of students passed the final exam on the dermatotherapy subject. Bivariate analysis revealed that the number of gadgets owned, digital usage and e- learning activities did not have a significant effect on the post-test score. Based on the students' feedback, blended learning had a positive impact on helping their learning process; however, the materials of e-learning must be interactive, informative and comprehensive. Face-to-face lecture is still an important component in learning hence it is irreplaceable.

Conclusion: Blended learning is an effective method of learning and should be considered if there is limitation of lecture time and number of teachers available. By using this method, medical students are more flexible in their study and it can be adjusted to their own learning style hence heling them understand better. Further development and improvement are needed for this method as to achieve the learning objectives.

Keywords: blended learning, dermatotherapy, medical students

\section{ABSTRAK}

Latar belakang: Terapi dermatologik merupakan salah satu mata ajar yang penting dalam Modul Praktik Klinik Dermatologi dan Venereologi (MPK-DV). Waktu yang dialokasikan untuk penyampaian materi terapi

*corresponding author, contact: susetyo_mr@yahoo.com 
dermatologik sangat singkat, sehingga diperlukan pengembangan metode pembelajaran yang efektif agar tujuan pembelajaran tercapai. Blended learning merupakan penggabungan metode e-learning dan kuliah tatap muka, seringkali digunakan bila ada keterbatasan waktu maupun jumlah pengajar. Metode ini diharapkan lebih efektif dan efisien baik dari pihak mahasiswa maupun pengajar. Penelitian ini bertujuan untuk mengetahui efektivitas metode blended learning dalam penyampaian materi ajar terapi dermatologik, serta mengidentifikasi hambatan yang terjadi.

Metode: Penelitian ini menggunakan rancangan potong lintang, dengan pendekatan kuantitatif dan kualitatif, melibatkan 22 orang mahasiswa tahun kelima yang sedang menjalankan rotasi MPK-DV di Fakultas Kedokteran Universitas Indonesia (FKUI). Data dikumpulkan dari kuesioner, pre dan posttest, ujian tulis akhir serta umpan balik dari mahasiswa. Perbandingan hasil pretest dan posttest dianalisis dengan menggunakan uji $\mathrm{T}$ berpasangan, kemudian dilanjutkan dengan uji bivariat terhadap penggunaan gawai, teknologi informasi dan aktivitas e-learning yang dihubungkan dengan peningkatan nilai posttest.

Hasil: Hasil penelitian menunjukkan terjadinya peningkatan nilai posttest, dan pada uji statistik terdapat perbedaan yang bermakna antara nilai pretest dan posttest $(\mathrm{P}<0,05)$. Sekitar $95,4 \%$ mahasiswa lulus ujian tulis akhir terkait terapi dermatologik. Pada uji bivariat, jumlah gawai, pemanfaat teknologi informasi dan durasi aktivitas e-learning, tidak berpengaruh terhadap peningkatan nilai posttest. Berdasarkan umpan balik, didapatkan bahwa metode blended learning membantu pembelajaran, namun masih diperlukan bahan ajar e-learning yang interaktif, informatif dan lengkap. Selain itu, kuliah tatap muka merupakan komponen penting yang tetap harus diadakan.

Kesimpulan: Blended learning merupakan metode pembelajaran yang efektif dan dapat dipertimbangkan bila terdapat keterbatasan waktu dan ketersediaan tenaga pengajar. Dengan metode ini mahasiswa dapat belajar lebih fleksibel dan sesuai dengan gaya belajar masing-masing, sehingga dapat meningkatkan pemahaman terhadap materi yang diajarkan. Masih diperlukan pengembangan dan penyempurnaan metode ini, agar tujuan pembelajaran tercapai.

Kata kunci: blended learning, terapi dermatologik, mahasiswa kedokteran

\section{PRACTICE POINTS}

- Dibutuhkan literasi digital yang baik untuk pengajar maupun mahasiswa.

- Penyediaan jaringan internet yang memadai.

- Tetap diperlukan kuliah tatap muka.

\section{PENDAHULUAN}

Terapi dermatologik khususnya terapi topikal, merupakan salah satu kompetensi penting yang harus dicapai oleh mahasiswa tahap klinik pada modul Praktik Klinik Dermatologi dan Venereologi (MPK-DV) dalam Kurikulum Berbasis Kompetensi (KBK). Hal ini diperlukan karena sebagian besar penyakit kulit termasuk dalam kompetensi 4A sesuai Standar Kompetensi Dokter Indonesia (SKDI), yang berarti dokter harus dapat melakukan tata laksana kasus hingga tuntas. ${ }^{1}$ Materi yang harus dikuasai mahasiswa ialah penentuan bahan aktif, vehikulum, bentuk sediaan dan cara penggunaannya, termasuk menuliskan resep. Penyiapan materi ajar disusun bersama antara staf pengajar Departemen Dermatologi dan Venereologi dengan staf pengajar Departemen Farmasi Kedokteran FKUI. Penyampaian materi ajar hanya dialokasikan 6 jam dari 4 minggu rotasi klinik. Materi ini diberikan pada hari ke-3 rotasi MPK-DV oleh seorang staf pengajar dari Departemen Farmasi. Penerapan terapi dermatologik dilakukan pada kegiatan pembelajaran 
bersama pasien di poliklinik, presentasi kasus, diskusi simulasi dan tutorial, dengan bimbingan staf pengajar dari Departemen Dermatologi dan Venereologi. ${ }^{2}$ Pada evaluasi hasil belajar, kompetensi terkait terapi dermatologik belum tercapai. Hal ini disebabkan oleh waktu yang singkat. Pada masa sebelum KBK, mahasiswa Program Studi Pendidikan Dokter (PSPD) mendapatkan rotasi Farmasi selama 5 minggu, termasuk praktikum pembuatan sediaan obat dan peresepan. Untuk mengatasi keterbatasan penyampaian materi ajar Farmasi dalam alokasi waktu yang singkat, diperlukan upaya untuk mencari metode pembelajaran alternatif yang sesuai, antara lain dengan metode blended learning.

Dalam beberapa tahun terakhir banyak publikasi yang membahas mengenai metode pembelajaran blended learning untuk berbagai bidang ilmu. Metode pembelajaran ini menggabungkan kuliah tatap muka dengan e-learning, dan pada umumnya metode ini dapat meningkatkan pengetahuan dan membantu proses pembelajaran menjadi lebih efektif dan efisien. ${ }^{3-6}$ Pada masa kini, generasi muda umumnya mudah mengikuti perkembangan teknologi informasi, seperti alat atau media digital yang semula hanya untuk hiburan misalnya mendengarkan musik. Alat digital ini berkembang menjadi smartphone yang digunakan untuk berbagai keperluan, berkomunikasi, mengirim surat elektronik/email, mencari literatur, e-book dan sebagainya. ${ }^{7}$ Perkembangan teknologi ini dimanfaatkan untuk pendidikan yang dikenal dengan e-learning, baik di sekolah dasar, menengah hingga perguruan tinggi.

Penggunaan blended learning memiliki beberapa keuntungan, antara lain mahasiswa dapat belajar sesuai dengan gaya belajar masing-masing, tidak terikat tempat dan tidak harus datang ke ruang kuliah. Banyak penelitian yang telah dilakukan menunjukkan bahwa mahasiswa lebih nyaman menggunakan metode blended learning dan merasakan manfaatnya, terutama dari aspek waktu dan tempat, ${ }^{8.10}$ walaupun masih ada kelompok mahasiswa yang lebih menyukai belajar dengan metode tatap muka. ${ }^{11}$ Dalam metode blended learning, mahasiswa dipacu untuk belajar mandiri dengan stres yang lebih ringan, dan dapat mengembangkan keterampilan mencari literatur secara digital. ${ }^{12,13}$ Di sekolah kedokteran, blended learning lebih sering digunakan pada tingkat preklinik dalam memelajari ilmu dasar, namun kini digunakan juga di tahap praktik klinik. ${ }^{4,13-15}$

Berdasarkantelaahberbagailiteraturterhadap manfaat blended learning, maka metode ini dipilih untuk diuji cobakan pada pembelajaran terapi dermatologik. Penelitian mengenai metode pembelajaran blended learning dalam bidang dermatologi dan venereologi belum pernah dilaporkan. Penelitian yang dilakukan ini merupakan penelitian pendahuluan untuk mendapatkan gambaran terkait efektivitas blended learning dan mengidentifikasi hambatan yang terjadi, yang akan dikembangkan untuk pembelajaran terapi dermatologik dalam MPK-DV di FKUI.

\section{METODE}

Penelitian ini merupakan studi potong lintang, dengan pendekatan kuantitatif dan kualitatif, pada satu kelompok mahasiswa PSPD FKUI tahap klinik yang sedang menjalani modul MPK-DV pada bulan November hingga Desember 2018 berjumlah 23 orang. Satu mahasiswa tidak mengikuti kegiatan pembelajaran, dengan demikian hanya 22 orang yang diikutkan dalam penelitian ini.

Rotasi klinik MPK-DV berlangsung selama 4 minggu, diawali dengan pengenalan materi umum dermatologi dan venereologi, terapi topikal dermatologik, dan pemeriksaan penunjang. Minggu kedua hingga ketiga, diisi dengan praktik poliklinik, rawat inap, diskusi kasus, termasuk penerapan dermatoterapi dalam penatalaksanaan kasus. Pada minggu keempat, dilakukan evaluasi pembelajaran melalui ujian tulis, ujian portofolio, ujian mini clinical examination (Mini-Cex) dan objective clinical skills examination (OSCE).

Pada pertemuan hari pertama minggu pertama MPK-DV, mahasiswa diberi penjelasan mengenai penelitian yang akan dilakukan, kemudian diminta kesediaannya untuk menandatangani informed consent. Selanjutnya, mahasiswa mengisi kuesioner secara online yang berisi pertanyaan seputar penggunaan gawai, teknologi digital serta e-learning. Akses terhadap materi ajar terapi dermatologik juga diberikan pada hari pertama melalui laman SCeLE (Student Centered e-Learning). Materi diberikan dalam 
bentuk video berupa narasi disertai gambar yang menjelaskan prinsip terapi dematologik, bentuk sediaan obat, bahan aktif maupun vehikulum.

Pada hari ke-3 minggu pertama MPK-DV, kegiatan diawali dengan pretest terkait materi terapi dermatologik untuk menilai kesiapan mahasiswa. Kegiatan dilanjutkan dengan kuliah tatap muka, diskusi interaktif dan simulasi pembuatan obat yang diberikan oleh staf pengajar Departemen Farmasi. Dalam proses belajar selanjutnya yaitu dimulai dari hari ke-4 minggu pertama sampai akhir minggu ketiga, dilakukan penerapan terapi dermatologik yang dikaitkan dengan tata laksana kasus klinik dibawah bimbingan staf pengajar dari Departemen Dermatologi dan Venereologi.

Pada hari terakhir minggu keempat, mahasiswa mengikuti ujian tulis akhir modul serta posttest. Lima belas dari 50 (30\%) soal ujian tulis akhir berkaitan langsung dengan terapi dermatologik. Soal yang lain (70\%) merupakan evaluasi pengetahuan terkait patogenesis penyakit, pemeriksaan penunjang, dan penegakkan diagnosis serta diagnosis banding.

Jumlah soal pretest maupun posttest sama banyak, yaitu 25 buah. Soal pretest berbentuk pilihan jawaban benar atau salah, sedangkan soal posttest berbentuk pilihan ganda, namun keduanya berupa pertanyaan yang sebanding. Hubungan antara pretest dan posttest dianalisis menggunakan uji $\mathrm{T}$ berpasangan. Selanjutnya dilakukan analisis bivariat terhadap hasil kuesioneryang berkaitan dengan jumlah kepemilikian gawai, teknologi digital (familiaritas, kenyamanan, kebiasaan) dan e-learning (durasi dan frekuensi akses) yang dihubungkan dengan peningkatan nilai posttest. Pada akhir modul, mahasiswa diminta memberikan umpan balik tertulis secara online terhadap proses pembelajaran dengan metode blended learning. Hasil kuesioner di awal modul dan umpan balik digunakan sebagai data kualitatif untuk memperkuat data yang dianalisis secara kuantitatif. Data dianalisis dengan menggunakan SPSS for Mac versi 21.

Penelitian ini telah mendapatkan persetujuan etik dari Harvard Human Research Protection Program, dengan nomor protokol IRB 18-1726 tahun 2018 dan dengan persetujuan Dekan Fakultas Kedokteran Universitas Indonesia (No.2591/UN2.F1.D1/ PPM.00.00/2018).

\section{HASIL DAN PEMBAHASAN}

Hasil penelitian kuantitatif diperoleh melalui nilai pretest, posttest dan ujian tulis akhir modul. Mahasiswa yang berpartisipasi dalam penelitian ini berjumlah 22 orang, laki-laki dan perempuan sama banyak. Seluruh mahasiswa lulus MPK-DV, dan 95,4\% mahasiswa dapat menjawab soal terkait terapi dermatologik dengan baik pada ujian tulis akhir. Hanya terdapat satu mahasiswa yang memperoleh nilai ujian terapi dermatologik di bawah batas lulus (Gambar 1).

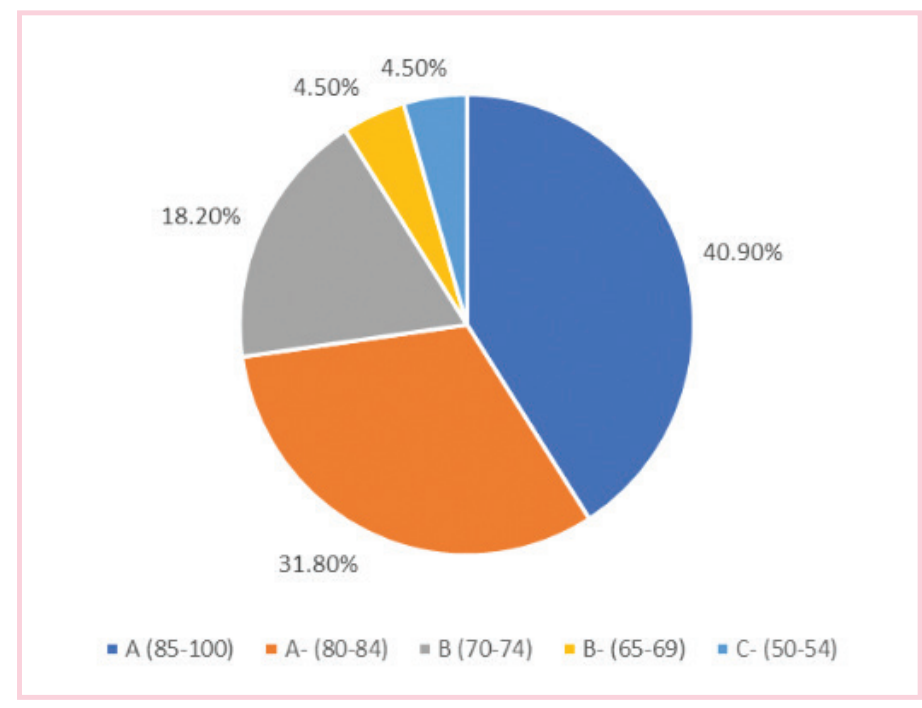

Gambar 1. Nilai ujian tulis terapi dermatologik ( $N=22)$ 
Perolehan nilai pretest terbanyak pada rentang nilai 60 hingga 69, dan terjadi peningkatan nilai posttest pada rentang 70 hingga 90 (Gambar 2).
Rerata nilai pre-posttest meningkat dari 60,55 menjadi 67,45. Nilai pretest dan posttest ini kemudian dianalisis dengan menggunakan uji

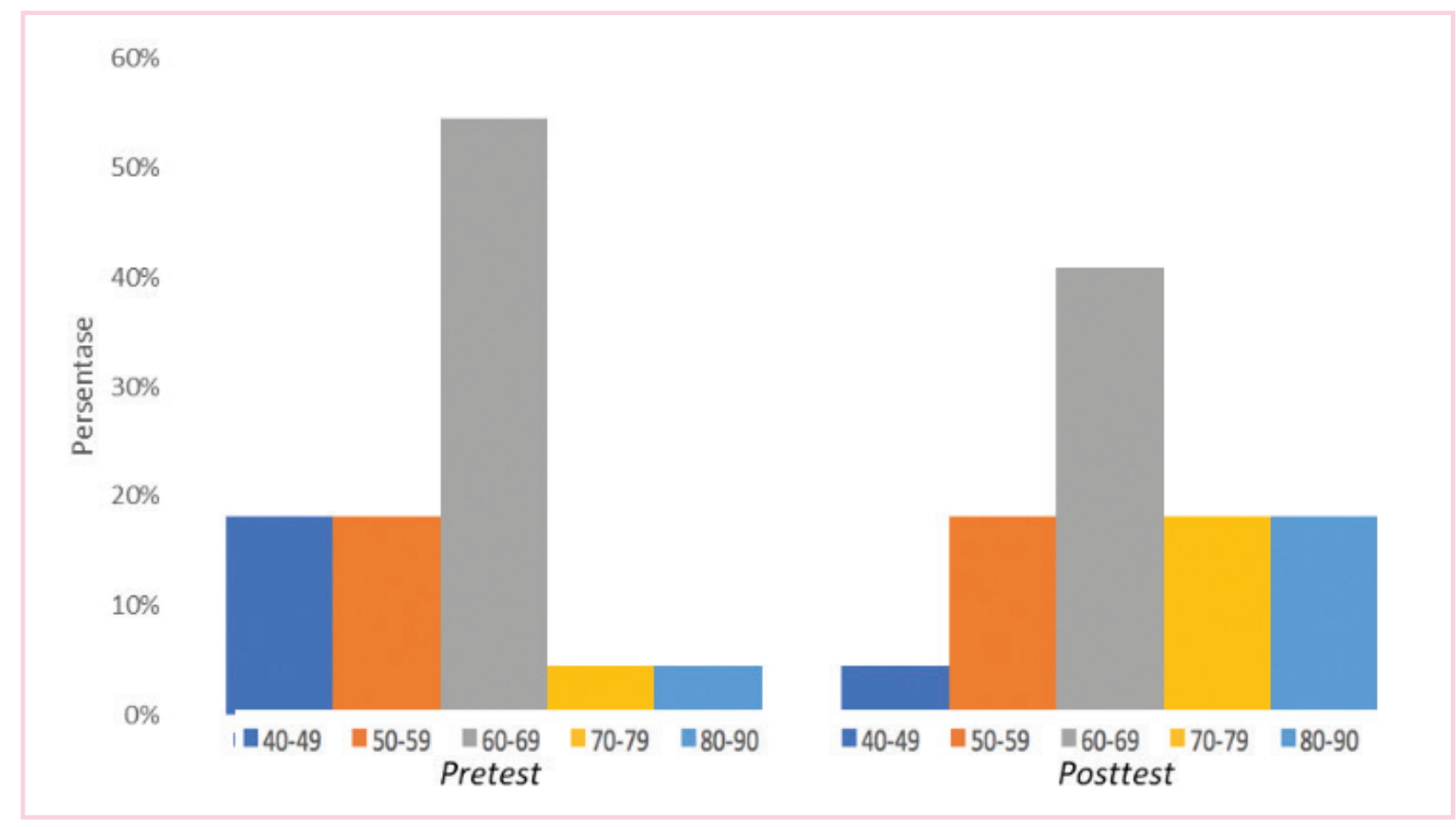

Gambar 2. Distribusi nilai pretest dan posttest

$\mathrm{T}$ berpasangan, dan didapatkan hasil bermakna $(\mathrm{p}<0,05)$, yang disajikan pada tabel 1 berikut ini.

Tabel 1. Nilai pretest dan posttest mahasiswa MPK-DV tahun 2018

\begin{tabular}{lccc} 
Kelompok & $\mathbf{n}$ & \multicolumn{1}{c}{ Rerata (SD) } & P \\
Pretest & 22 & $60,55(50,5-70,6)$ & $0,019^{*}$ \\
Posttest & 22 & $67,45(56,96-77,94)$ & \\
\hline
\end{tabular}

${ }^{*}$ Uji t berpasangan

Hasil penelitian kualitatif diperoleh dari kuesioner dan umpan balik, untuk memperkuat hasil penelitian kuantitatif. Berdasarkan hasil kuesioner didapatkan seluruh mahasiswa memiliki koneksi internet di rumah atau di tempat tinggalnya (pondokan).
Mahasiswa memiliki jumlah gawai yang bervariasi, namun pada umumnya lebih dari satu buah gawai (handphone, komputer laptop, tablet). Jumlah gawai yang dimiliki mahasiswa tidak berpengaruh secara bermakna terhadap peningkatan nilai posttest mahasiswa. Mahasiswa yang nilainya meningkat, ternyata lebih familiar, nyaman dan terbiasa dalam menggunakan teknologi digital, walaupun hasilnya secara statistik tidak bermakna. Selain itu, didapatkan bahwa mahasiswa yang nilainya meningkat lebih sering mengakses materi online dengan total durasi yang lebih singkat. Data yang diperoleh dari lembar kuesioner terkait penggunaan gawai dan teknologi digital, dihubungkan dengan peningkatan nilai preposttest. Selanjutnya dilakukan analisis dengan uji bivariat dan disajikan pada tabel 2 berikut. 
Tabel 2. Hubungan penggunaan gawai, teknologi digital dan aktivitas e-learning terhadap peningkatan nilai pre-posttest mahasiswa $(\mathrm{N}=22)$

\begin{tabular}{|c|c|c|c|}
\hline Variabel & $\begin{array}{l}\text { Nilai meningkat } \\
\quad n=11(\%)\end{array}$ & $\begin{array}{l}\text { Nilai tidak meningkat } \\
\qquad n=11(\%)\end{array}$ & Nilai $p$ \\
\hline $\begin{array}{l}\text { Jumlah gawai* } \\
\begin{array}{l}1-3 \\
>3\end{array}\end{array}$ & $\begin{array}{l}6(54,54) \\
5(45,45)\end{array}$ & $\begin{array}{l}7(63,63) \\
4(36,36)\end{array}$ & 1,000 \\
\hline Familiaritas terhadap teknologi ${ }^{* *}$ & $1,55(0,92-2,17)$ & $1,27(0,53-2,01)$ & 0,539 \\
\hline Kenyamanan menggunakan teknologi** & $22,27(21,03-23,51)$ & $21,82(20,55-23,09)$ & 0,575 \\
\hline Kebiasaan menggunakan internet** & $15(14,05-15,95)$ & $15,36(13,71-17,02)$ & 0,677 \\
\hline Durasi akses materi e-learning $(\mathrm{jam})^{* * *}$ & $37(8-231)$ & $48(3-170)$ & 0,606 \\
\hline Frekuensi akses materi e-learning ${ }^{* * *}$ & $4(2-6)$ & $2(1-7)$ & 0,171 \\
\hline
\end{tabular}

Keterangan: *data berbentuk kategorik disajikan dalam bentuk frekuensi

** rerata (standar deviasi)

*** median (nilai minimum-maksimum)

Hasil umpan balik yang diperoleh secara online, menunjukkan bahwa sebagian besar mahasiswa mengatakan tidak ada kesulitan dalam mengakses materi e-learning. Namun, terkadang akses e-learning tidak mudah, bergantung pada sarana internet di area tempat tinggal mereka.

“... ya, akses internet yang sulit” (B, perempuan)

"... sulit apabila tidak tersedia koneksi yang bagus" (T, laki-laki)

Para mahasiswa merasa penggunaan SCeLE sebagai platform e-learning cukup user-friendly, seperti kutipan berikut:

"... sudah user-friendly, namun belum cukup interaktif" ( $P$, perempuan)

“... sudah akrab bagi pengguna karena sudah menggunakan sejak 3 tahun ...." (H, laki-laki)

"... ya. Karena sudah menggunakan SCeLE sejak tingkat 1 ...." (B, perempuan)

Berkaitan dengan materi ajar, terdapat juga beberapa mahasiswa yang merasa bahwa isi video yang diberikan perlu diperbaiki, seperti kutipan berikut:
"... video yang diberikan berisi slide dan orang berbicara, video kurang interaktif sehingga cenderung membuat orang mengantuk" (E, perempuan)

Salah seorang mahasiswa menyatakan bahwa materi video tersebut tidak lengkap, seperti kutipan singkat yang disampaikan berikut ini

“... kurang lengkap” ( $R$, laki-laki)

Kutipan yang sangat singkat ini tidak diikuti dengan wawancara, sehingga tidak diperoleh informasi yang lebih jelas tentang maksud pernyataan tersebut.

Selain itu, mereka merasa materi online yang diberikan belum cukup dan tetap membutuhkan diskusi tatap muka dengan durasi yang memadai seperti kutipan berikut:

"... saya masih belum siap untuk metode pembelajaran seperti ini, karena saya merupakan tipe orang yang lebih senang melihat dan mendengarkan narasumber secara langsung ...." (M, perempuan)

".... waktu sesi feedback kurang sehingga menimbulkan banyak kebingungan terkait teori yang jelas ...." (J, laki-laki) 
Selama mengikuti blended learning, sebagian besar mahasiswa menyampaikan bahwa metode ini membantu pembelajaran dengan alasan yaitu:

“... menurut saya cukup membantu ... mahasiswa dipacu untuk mempersiapkan diri belajar sebelum esok hari diberikan kuliah ...." (H, laki-laki)

“... ya, karena dengan metode ini menuntut kami untuk belajar terlebih dahulu untuk bisa menghadapi tahapan berikutnya" (E, perempuan)

Hasil penelitian ini menunjukkan bahwa metode blended learning dapat digunakan dalam MPK-DV, khususnya mempelajari terapi dermatologik. Alokasi waktu yang dirasakan staf pengajar terlalu singkat dalam menyampaikan materi, dapat teratasi dengan memanfaatkan e-learning, antara lain penelusuran literatur dan penyelesaian tugas. Tatap muka dilakukan untuk diskusi interaktif dan klarifikasi hal-hal yang belum jelas, dan dipandu oleh pengajar yang pakar di bidang farmasi. Pengetahuan terapi dermatologik yang diperoleh mahasiswa di minggu pertama ini, diterapkan dalam praktik klinik selama minggu kedua hingga keempat modul MPK-DV. Para pengajar bidang dermatologi berperan sebagai tutor dan memberikan pengayaan selama stase praktik klinik. Metode blended learning ini memungkinkan pengajar melakukan observasi serta evaluasi kemampuan kognitif, psikomotor, bahkan afektif mahasiswa.

Tidak berbeda dengan para peneliti terdahulu, secara umum terjadi peningkatan pengetahuan setelah mahasiswa memelajari materi yang diberikan secara online. ${ }^{8-10}$ Peningkatan pengetahuan dan kemajuan belajar pada penelitian ini dapat dinilai melalui preposttest, dan didapatkan hasil yang bermakna. Secara keseluruhan proses pembelajaran ini dimulai dengan e-learning, diikuti dengan tatap muka, diskusi interaktif dan pendampingan selama penerapan dalam praktik klinik, sehingga dapat meningkatkan kompetensi dan keterampilan. Temuan lain pada penelitian ini ialah, didapatkannya 95,4\% mahasiswa lulus ujian tulis akhir terkait materi terapi dermatologik. Data ini dapat menggambarkan pencapaian tujuan pembelajaran yang sangat baik. Hanya satu orang mahasiswa yang mendapatkan nilai di bawah batas lulus. Namun, tidak dilakukan penelusuran lebih lanjut untuk mengetahui kendala yang terjadi pada mahasiswa tersebut.

Peningkatan pengetahuan dengan menggunakan metode e-learning ini sejalan dengan penelitian yang dilakukan oleh Sung, dkk., ${ }^{8}$ Maryani, dkk., ${ }^{9}$ dan Fandianta, dkk. ${ }^{10}$ Sung $^{8}$ menambahkan bahwa e-learning dapat mengurangi waktu dosen untuk mengajar dan meningkatkan efektivitas biaya pendidikan. Sedangkan Maryani ${ }^{9}$ pada penelitiannya di Jurusan Kesehatan Gigi Poltekkes KemenKes Pontianak, memilih metode blended learning untuk mengatasi jumlah dosen yang tidak mencukupi. Selain itu, Fandianta ${ }^{10}$ juga memanfaatkan metode ini untuk penyelesaian tugas termasuk pelaksanaan kuis dan ujian.

Manfaat lain dari penggunaan metode blended learning ini ialah memungkinkan mahasiswa belajar dengan gaya belajar mereka masing-masing, tidak terikat waktu dan tempat. Selain itu, mereka memiliki lebih banyak waktu luang untuk mengeksplorasi dan memperdalam sumber belajar lainnya di luar yang diberikan. Namun, dalam proses pembelajaran di fakultas kedokteran di tingkat klinik, tatap muka berperan penting, karena tetap dibutuhkan panutan seorang pengajar dalam menjalankan profesi sebagai dokter. Tidak dapat dipungkiri bahwa narasumber untuk umpan balik sangat diperlukan, karena pada kesempatan tersebut dapat digunakan untuk berbagi pengalaman yang tidak tertuang di dalam buku ajar.

Salah satu kuesioner yang dikutip dalam penelitian ini, didapatkan pernyataan bahwa metode belajar dengan tatap muka masih diperlukan, karena lebih mudah mendapat penjelasan langsung dari pengajar. $\mathrm{Hal}$ ini sesuai dengan penelitian Morton, ${ }^{4}$ yang menyampaikan bahwa dalam blended learning tetap diperlukan sosok pengajar untuk menumbuhkan keterampilan berpikir, seperti sintesis dan evaluasi pengetahuan. Nortwig ${ }^{5}$ dalam penelitiannya juga mendapatkan, bahwa keberhasilan metode blended learning tidak lepas dari peran pengajar yang mampu memotivasi mahasiwa belajar, di samping materi ajar yang diberikan harus berkualitas.

Menilik manfaat metode blended learning dalam proses belajar di MPK-DV, maka perlu digali 
kesiapan mahasiswa, pengajar dan sarana penunjang untuk melaksanakan metode tersebut pada kegiatan selanjutnya. Generasi muda saat ini lebih akrab dengan kemajuan teknologi digital, antara lain untuk keperluan hiburan, pergaulan sosial, termasuk pendidikan. Berdasarkan kutipan umpan balik pada penelitian ini, seluruh mahasiswa memiliki dan dapat menggunakan jaringan internet di tempat tinggal masing-masing. Para mahasiswa dapat mengikuti kegiatan pembelajaran melalui metode blended learning, dan hanya sebagian kecil di antaranya lebih menyukai gaya belajar tradisional dengan tatap muka. Pendapat mahasiswa bahwa pembelajaran dalam kelas lebih menarik dan meningkatkan motivasi dibandingkan dengan cara online, didapatkan pula pada penelitian Wright. ${ }^{11}$ Platform e-learning yang user friendly dapat membantu keberhasilan blended learning, namun, tetap perlu diwaspadai hambatan yang terjadi, seperti ketersediaan jaringan internet yang kurang memadai.

Pada penelitian yang dilakukan ini, mahasiswa dengan nilai posttest meningkat ternyata memiliki familiaritas dan kenyamanan, sehingga terkait durasi, mereka lebih sering mengakses materi e-learning dengan total durasi yang lebih singkat. Kebiasaan menggunakan internet juga merupakan faktor yang berhubungan dengan keberhasilan mahasiswa untuk mengikuti metode blended learning. Keadaan ini dimungkinkan karena mahasiswa sudah terbiasa menggunakan teknologi digital sejak tahun pertama pendidikan, bahkan mungkin sejak pendidikan sebelumnya. Penelitian ini sejalan dengan penelitian oleh Tang, dkk. ${ }^{12}$ yang menyimpulkan, bahwa kemampuan literasi digital mahasiwa dan pengajar merupakan prasyarat keberhasilan blended learning. Jika belum cukup menguasai, seyogianya dilakukan pelatihan terlebih dahulu..$^{10,12}$

Blended learning sangat membantu mahasiswa belajar karena mereka telah menyiapkan diri sebelumnya, seperti kutipan umpan balik mahasiswa pada penelitian ini. Hal ini sesuai dengan penelitian Shantakumar, ${ }^{13}$ yang menyimpulkan bahwa stres mahasiswa berkurang dan timbul rasa percaya diri, karena mereka telah mempersiapkan diri sebelum diskusi tatap muka dilakukan. Rasa percaya diri ini penting dalam proses pembelajaran, karena dapat meningkatkan hasil belajar. Langenau ${ }^{14}$ juga mendapatkan, bahwa pendekatan blended learning sangat membantu mahasiswa memahami materi ajar, terlatih untuk belajar mandiri dan berdampak pula pada peningkatan rasa percaya diri. Hasil penelitian ini juga tidak berbeda dengan penelitian oleh Shimizu dkk. ${ }^{15}$ Pada penelitian tersebut disimpulkan bahwa mengombinasikan e-learning dalam metode PBL, menyebabkan mahasiswa lebih termotivasi untuk belajar yang disertai perbaikan perilaku belajar mandiri, bila dibandingkan dengan PBL tanpa e-learning.

Keterbatasan pada penelitian pendahuluan ini ialah tidak dilakukan pengumpulan nilai ujian tulis terkait terapi dermatologik sebelum menggunakan metode e-learning. Penilaian efektivitas dapat juga dinilai melalui diskusi interaktif dan tugas yang diberikan, namun hal tersebut tidak dilakukan dalam penelitian ini. Selain itu, umpan balik dari staf pengajar tidak dilakukan, sehingga tidak diketahui kendala yang terjadi saat melaksanakan metode blended learning dari aspek pengajar.

\section{KESIMPULAN}

Melalui blended learning, mahasiswa dapat belajar secara mandiri dan lebih siap pada saat melakukan diskusi tatap muka, yang didukung oleh pendapat mahasiswa melalui umpan balik. Efektivitas blended learning pada penelitian ini dapat dilihat dari peningkatan nilai posttest yang bermakna. Hambatan pelaksanaan metodeblendedlearningyang diidentifikasi pada penelitian ini antara lain, akses internet yang kurang baik dan materi e-learning yang belum cukup informatif. Hasil penelitian pendahuluan ini dapat digunakan untuk mengembangkan penelitian selanjutnya dengan beberapa perbaikan, seperti pelatihan untuk meningkatkan kemampuan literasi digital baik untuk mahasiswa maupun staf pengajar, dan melengkapi data kualitatif yang dibutuhkan.

\section{SARAN}

Pada penelitian mendatang sebaiknya data kualitatif yang akan dikumpulkan dipersiapkan lebih baik dan dianalisis lebih rinci. Umpan balik dari para pengajar diperlukan untuk melengkapi data penelitian. 
Selain itu, diperlukan wawancara mendalam untuk mengklarifikasi pernyataan dalam umpan balik yang belum jelas. Untuk mendapatkan hasil yang lebih akurat, sebaiknya digunakan responden yang lebih banyak.

\section{DEKLARASI KEPENTINGAN}

Para penulis mendeklarasikan bahwa tidak terdapat konflik kepentingan apapun terkait studi pada naskah ini.

\section{KONTRIBUSI PENULIS}

Sri Linuwih Menaldi - sebagai penulis utama, pemberi ide penelitian, dan pengolahan data.

Hanny Nilasari - sebagai penulis pendamping dan pengelola modul praktik klinik Dermatologi dan Venereologi.

Githa Rahmayunita - sebagai penulis pendamping, penanggung jawab materi Dermatoterapi, dan pengolahan data.

Siti Farida - sebagai penulis pendamping dan pemberi materi Dermatoterapi.

Nanda L. Prasetya - sebagai penulis pendamping, pelaksana penelitian di lapangan, dan analisis statistik.

\section{DAFTAR PUSTAKA}

1. Konsil Kedokteran Indonesia. Standar Kompetensi Dokter Indonesia. Jakarta: Konsil Kedokteran Indonesia. 2012; pp. 54-56.

2. Buku Rancangan Pengajaran Modul Praktik Klinik Dermatologi dan Venereologi Fakultas Kedokteran Universitas Indonesia Tahun Ajaran 2017-2018. Jakarta: Fakultas Kedokteran Universitas Indonesia. 2017.

3. Fadde PJ, Vu P. Blended online learning: benefits, challenges and misconceptions. Dalam: Lowenthal PR, York CS and Richardson JC (ed). Online learning: common misconceptions, benefits and challenges. New York: Nova Publishers. 2014; pp. 33-48.

4. Morton CE, Saleh SN, Smith SF, Hemani A, Ameen A, Bennie TD, Toro-Troconis M. Blended learning: how can we optimise undergraduate student engagement?. BMC Medical Educ. 2016 Dec;16(1): 195

5. Nortvig AM, Petersen AK, Balle SH. A literature review of the factors influencing e-learning and blended learning in relation to learning outcome, student satisfaction and engagement. Electronic Journal of E-learning. 2018;16(1):4655.

6. Sharp L, Karadzhov D, Martin JL. The curious case of blended learning: an evaluation of a curriculum innovation in the Global Mental Health Master's Programme. J Med Educ. 2018;17:149-59.

7. Sandars JE, Frith GS. Mobile learning (m-learning). Dalam: Dent JA, Harden RM. A Practical Guide for Medical Teachers. Edisi ke4. London: Churchill Livingstone. 2013; pp. 231-36.

8. Sung YH, Kwon IG, RYU E. Blended learning on medication administration for new nurses: Integration of e-learning and face-to-face instruction in the classroom. Nurse Educ Today. 2008;28:943-52.

9. Maryani Y. Aplikasi Elearning sebagai model pembelajran berbasis teknologi informasi di Jurusan Kesehatan Gigi Poltekkes Lemenkes Pontianak. Jurnal Vokasi. 2013;9:27-39.

10. Fandianta, Sanjaya GY. Widyandana. Meningkatkan pengetahuan mahasiswa dengan memberikan fleksibilitas belajar mengajar melalui metode blended learning. Jurnal Pendidikan Kedokteran Indonesia. 2013;2(2):1-8

11. Wright BM. Blended learning: student perception of face-to-face and online EFL lessons. Indones. J. Appl. Linguist. 2017; 7: 64-71

12. Tang CM, Chaw LY. Digital Literacy: A Prerequisite for Effective Learning in a Blended Learning Environment? Electronic Journal of E-learning. 2016;14:54-65.

13. Shantakumari N, Sajith I. Blended learning: The student viewpoint. Ann Med Health Sci Res. 2015;5:323-28. 
14. Langenau EE, Lee R, Fults M. Blended learning educational format for third-year paediatrics clinical rotation. J Am Osteopath Assoc. 2017 April; 117: 234-43. https://doi.org/10.7556/ jaoa.2017.041
15. Shimizu I, Nakazawa H, Sato Y, Wolfhagen IHAP, Konings KD. Does blended problembased learning make Asian medical students active learners?: a prospective comparative study. BMC Med Educ. 2019;19:147-55. 